\title{
Review of the generic level classification of New World Mantispidae (Neuroptera)
}

\author{
Norman D. Penny (')
}

\begin{abstract}
The higher classification of New World Mantispidae is reviewed. Keys are provided to subfamilies, tribes and genera for the New World. The genus Fusa is synonomized with Gerstaeckerella, Nobrega with Climaciella, Bellarminus with Nolima; Anchieta is resurrected. The genus Mantispa is divided into four species groups, and the genus Entanoneura is redefined.
\end{abstract}

\section{INTRODUCTION}

Mantispidae are distinctive members of the Neuroptera, with elongate pronota and raptorial forelegs. In these respects they closely resemble praying mantids, but the wing venation and complete life cycle readily identify them as neuropterans. All mantispids are parasitic on other arthropods, from spider eggs to aculeate wasps to scarab beetles and lepidopterous larvae.

Eggs are laid on short stalks in large numbers on tree trunks. Upon hatching, the young larvae will hide under bark seeking out suitable hosts (McKeown \& Mincham, 1948).

\section{SySTEMATICS}

There never has been a modern, comprehensive treatment of the whole family, although the basic classification was first proposed by Enderlein (1910). Rehn (1939) reviewed the higher classification for North America and Williner \& Kormilev (1959) described the species from Argentina. Handschin (1960) described some species of Mantispinae for South America, while Parker \& Stange (1965) reviewed the status of the Platymantispini.
Stange (1968) listed the species from Argentina, and Penny (1977) listed 111 species in 15 genera for South and Central America.

Family MANTISPIDAE Leach, 1815

Mantispidae Leach, 1815, Edinb. Encyclop., 9: 139.

Type Genus: Mantispa Illiger (1798).

Adult Mantispidae are separated from other neuropterous families by the short antennae, numerous unbranched costal crossveins of the wing, elongate prothorax and raptorial forelegs. Larvae are scarabaeiform with short mandibles not bearing internal teeth. The family is found throughout temperate and tropical America, although they are much more common in the tropical zone. The family is usually divided into two subfamilies, although Lambkin (personal communication) indicates that a new study, soon to be published, will break the Platymantispinae into three subfamilies.

\section{KEY TO SUBFAMILIES OF MANTISPIDAE}

1a. Anterior tarsi each with only one claw and without arolia (Fig. 2) ...... Mantispinae

1b. Anterior tarsi each with two claws and an arolium (Fig. 1) ....... Platymantispinae

Subfamily PLATymantispinae Rehn, 1939b

Symphrasini Navás, 1909, Mem. R. Acad. cienc. artes Barcelona, 7 (10): 484. (invalid name, based on sy. nonomized generic name).

Anisopterinae Enderlein, 1910, Stett. ent. Ztg., 71: 342. (invalid name, bøsed on a homonomous generic name).

Platymantispinae Rehn, 1939b, Ent. News, 50: 82. ( $\left.{ }^{2}\right)$

(1) - Instituto Nacional de Pesquisas da Amazônia, Manaus.

(2) - The name Platymantispinae would also be invalid because the type genus name Platymantispa is a junior sy nonym of Anchieta. However, Article 40 of the International Code of Zoological Nomenclature indicates that the name Platymantispinae must be retained, as the invalidity of its type genus was not recorded before 1961. 

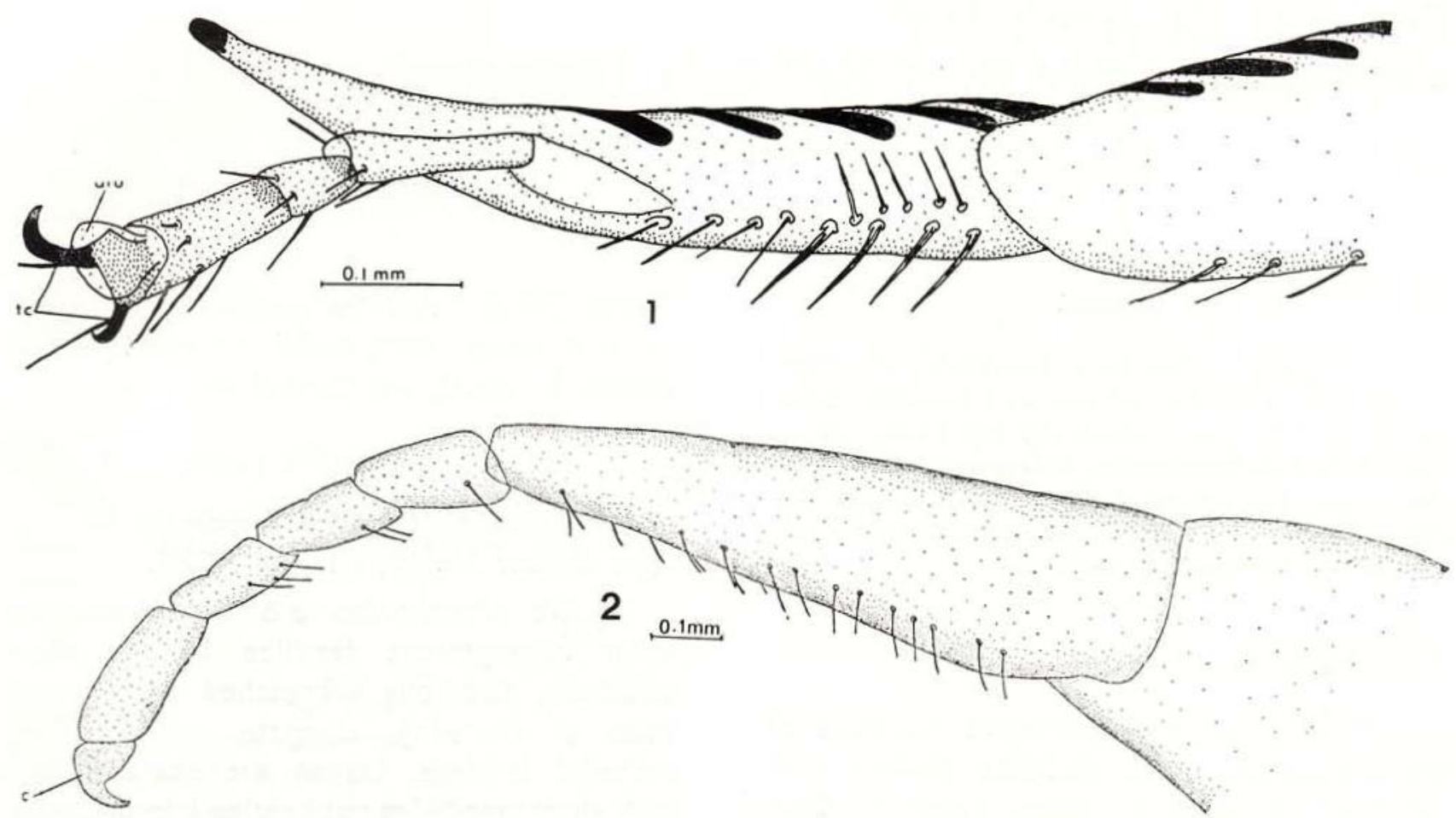

Figures 1-2 - Lateral view of right tarsi of 1) Trichoscelia varia (Walker) and 2) Mantispa interrupta Say. aro $=$ arolium, tc $=$.tarsal claw.

Type Genus: Platymantispa Rehn, now considered a synonym of Anchieta.

This subfamily is the smaller in number of species, and is confined to Australia and the Americas. There are two claws on the fore tarsi. Although the Platymantispinae are easily identified, much confusion has existed as to the name. For a fuller discussion of synonomy, see the sections on Trichoscelia and Anchieta.

The Platymantispinae are generally divided into four American tribes: Platymantispini, Theristriini, Drepanicini and Nolimini.

\section{KEY TO TRIBES OF PLATYMANTISPINAE}

1a. Anterior first tarsal segment with a dentiform process (Fig. 1); adult female bearing ovipositor (Fig. 4); male penisfilum coiled (Fig. 3) ......... Platymantispini

1b. Anterior first tarsal segment without dentiform" process; adult fema'e not bearing ovipositor; male penisfilum not coiled . 2 2a. Subcosta of forewing entering costal margin far anterior to pterostigma (Fig. 8); fore tarsal claws bifid ......... Nolimini

2b. Subcosta of forewing entering costal margin in area of pterostigma (Fig. 9); fore tarsal claws not forked ......... 3

3a. Pterostigma of forewing isolated from $R_{1}$; only one Sc crossvein (Fig. 9) . Drepanicini

3b. Pterostigma filling costal area between $R_{1}$ and forewing margin; two Sc crossveins (Fig. 7) $\ldots \ldots \ldots \ldots \ldots \ldots$ The istriini

\section{Tribe Drepanicini Enderlein}

Drepanicini Enderiein, 1910, Stett. ent. Ztg., 71: 343.

Type Genus: Drepanicus Blanchard (1851), designated by Enderlein (1910).

There is only one known genus of this tribe in the New World: Drepanicus Blanchard from Chile and Argentina. 

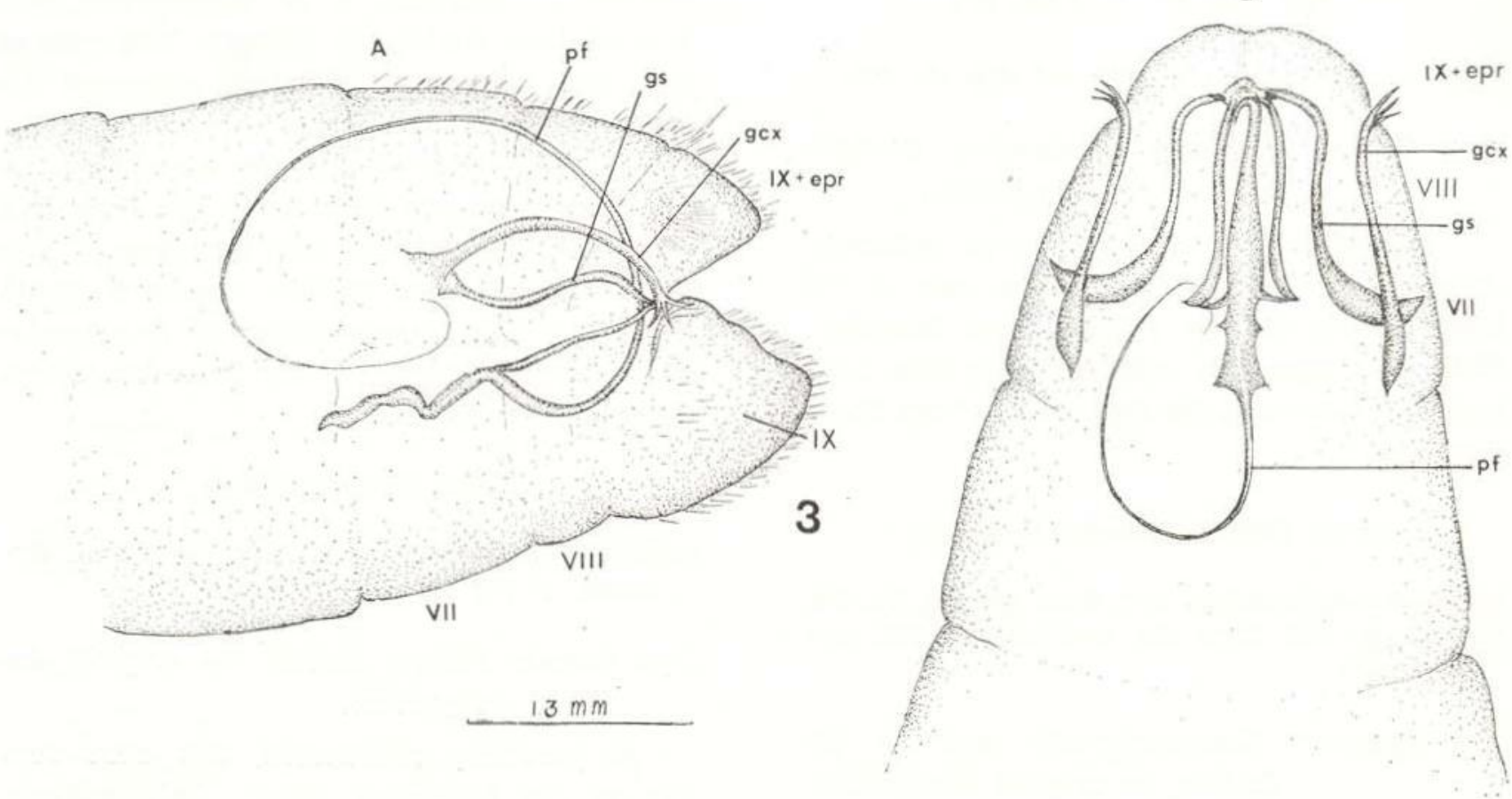

Figure 3 - Abdomen of Trichoscelia santaremi Navás A. Lateral view. B. Dorsal view, epr $=$ ectoproct, gs $=$ gonarcus, gcx $=$ gonocoxite, $\mathrm{pf}=$ penisfilum.
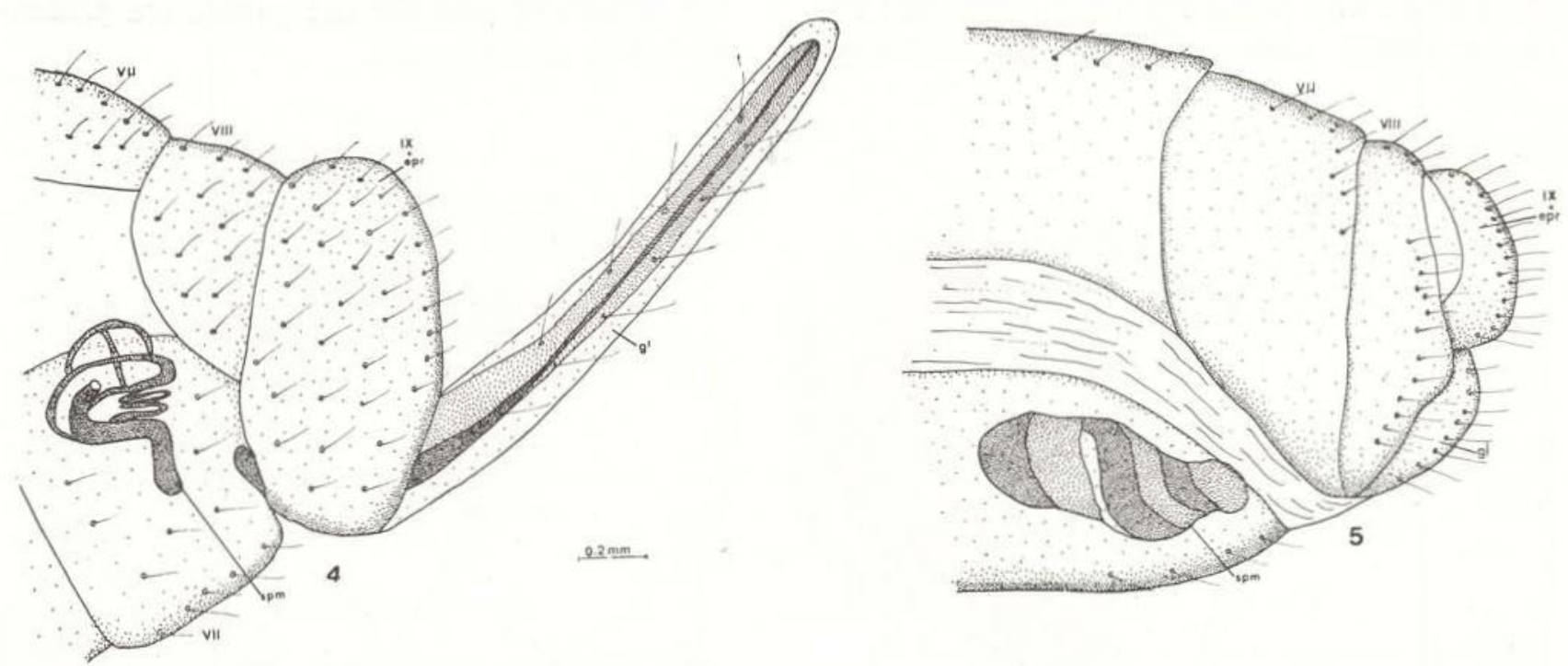

Figures 4-5 - Lateral view of abdomen of 4) Trichoscelia varia (Walker) (female), and 5) Mantispa flavomaculata Latreille (female). epr $=$ ectoproct, $\mathrm{gl}=$ gonapophyses laterales, $\mathrm{spm}=$ spermatheca.

\section{Genus Drepanicus Blanchard}

Drepanicus Blanchard, 1851, in Gay, Histoire fisica de Chile, 6: 130 .

Molinella Navás, 1910, Revta chil. Hist. nat., 14: 239.

Type Species: Drepanicus gayi Blanchard, designated by Enderlein (1910).
This genus is only known from two species, $D$. gayi and $D$. chrysopinus Brauer. All specimens are large and green, and Drepanicus gayi appears very similar to the leaf-mimicing katydids (Orthoptera: Tettigoniidae). The genus Molinella Navás was synonomized with Drepanicus by Banks (1913). 
Tribe Theristriini Enderlein

Theristriini Enderlein, 1910, Stett. ent. Ztg., 71: 343.

Type Genus: Theristria Gerstaecker, designated by Enderlein (1910).

This tribe has a distinctly longer subcostal vein and completely free medius vein of the wing, lacking in the related tribe Nolimini. Only one genus is recognized in this tribe from the Americas, Gerstaeckerella from South America.

\section{Genus Gerstaeckerella Enderlein}

Gerstaeckerella Enderlein, 1910, Stett. ent. Ztg., 71: 368. Fusa Navás, 1925, Revta chil. Hist. nat., 29: 307. new synonomy.

Type Species: Gerstaeckerella gigantea Enderlein, by original designation. Type species of Fusa is Fusa pirioni Navás, by monotypy.

This is the only South American genus of Theristriini. The genus Fusa was described by Navás (1925) without giving differentiating characters. However, it is synonomous with Gerstaeckerella chilensis (Hagen). This species does not differ markedly from others of the genus, although it is the smallest species. Penny (1977) mentioned seven species in the two genera, ranging from Chile and Argentina north to Colombia. The only specimen of this genus known from outside southern South America is the type specimen of Gerstaeckerella gigantea Enderlein. The Colombia record is probably erroneus.

\section{Tribe Nolimini Navás}

Nolimini Navás, 1914, Mem. R. Acad. cienc. artes Barcelona, 11 (7): 100 .

Type Genus: Nolima Navás, by original designation.

As presently constituted, this tribe consists of one Australian genus, Calomantispa, and one Central American genus, Nolima. The character separating the two nominal American genera is a very weak one (relative length of the pronotum), and the two genera are presently being synonomized.

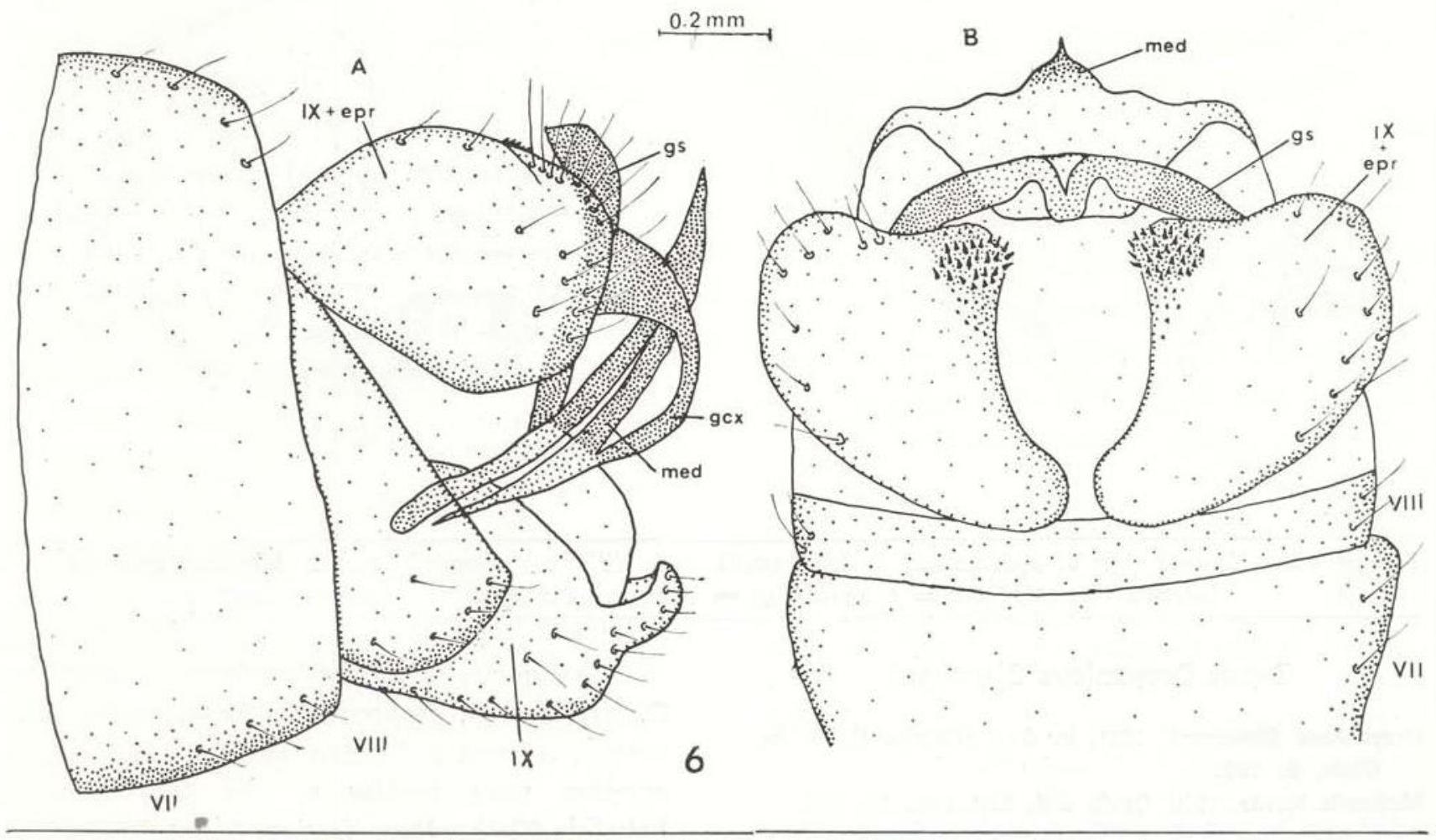

Figure 6 - Abdomen of Mantispa flavomaculata Latreille (male). A. Lateral view. B. Dorsal view. epr $=$ ectoproct, gs $=$ gonarcus, gcx $=$ gonocoxite, med $=$ mediuncus . 


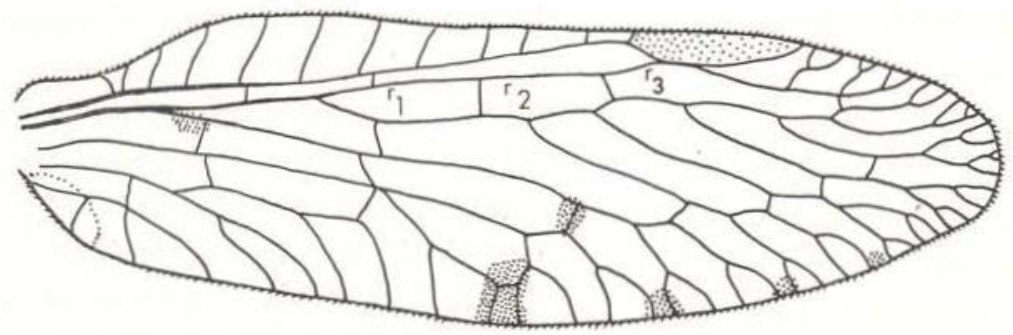

7
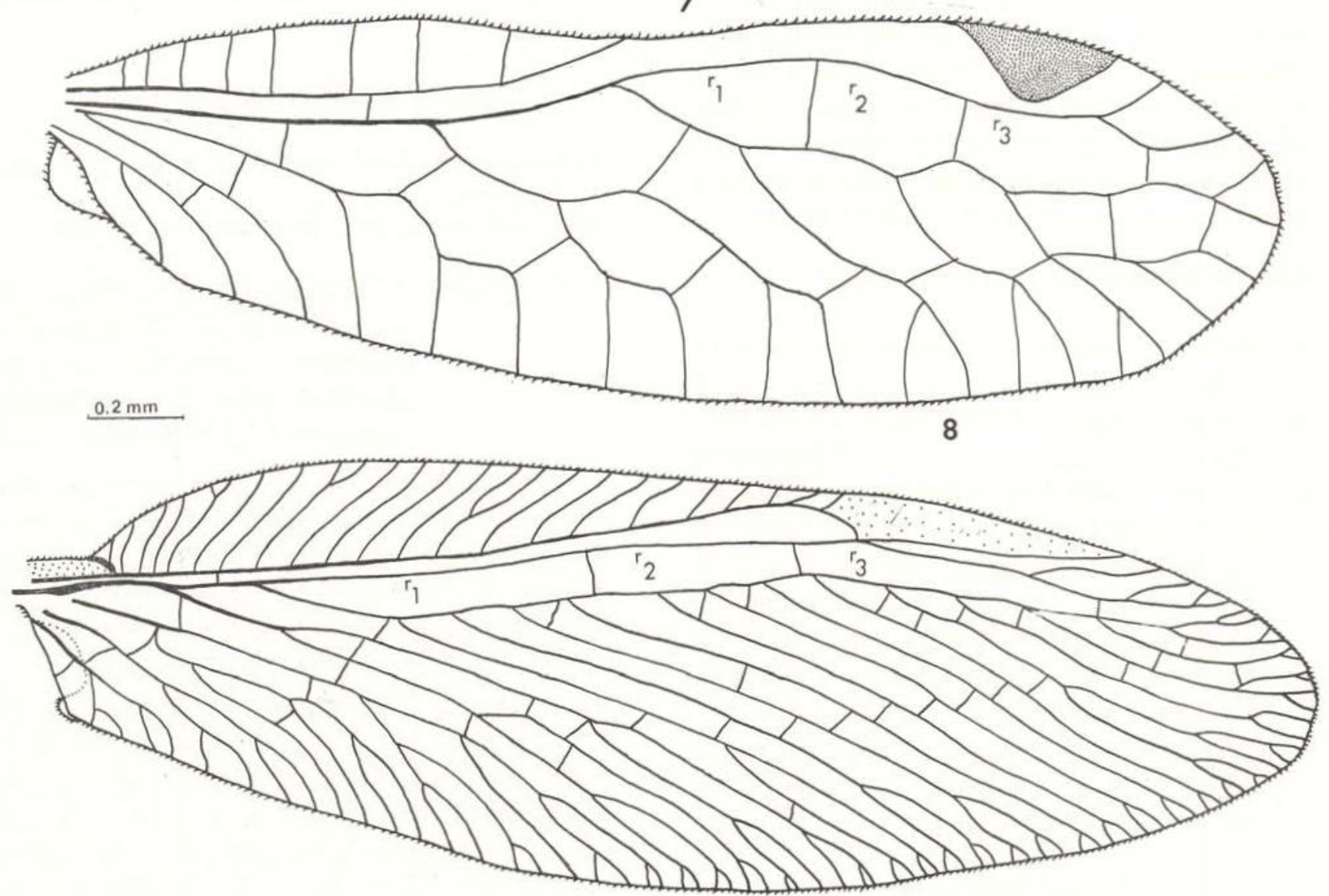

9

Figures 7-9 - Right forewings of 7) Gerstaeckerella chilen sis (Hagen), 8) Nolima infensus Navás (modified from Navás, 1924), and 9) Drepanicus chrysopinus Brauer. $r_{1}=$ first radial cell, $r_{2}=$ second radial cell, $r_{3}=$ third radial cell.

\section{Genus Nolima Navás}

Nolima Navás, 1914a. Mem. R. Acad. cienc. artes Barcelona, 11 (7): 100.

Bellarminus Navás, 1914a, Mem. R. Acad. cienc. artes Barcelona, 11 (7): 102. (new synonomy).

Type Species: Nolima victor Navás, by original designation.

This genus has been separated from Bellarminus by the shorter, wider pronotum. After examining the type species of Bellarminus in the Paris Museum, no substantial differences could be noted, except that $B$. pugnax is the smallest known species of this genus, and the pronotum is proportionally somewhat narrower. This author does not feel that these differences are sufficient for generic recognition.

\section{Tribe Platymantispini Rehn}

Symphrasini Navás, 1909, Mem. R. Acad. cienc. artes Barcelona, 7 (10): 484 . (invalid name, based on a synonomized generic name).

Anisopterini Enderlein, 1910, Stett. ent. Ztg., 71: 343 (invalid name, based on a homonomous generic name).

Platymantispini Rehn, 1939b, Ent. News, 50: 82. 
Type Genus: Platymantispa Rehn, designated by Rehn (1939b).

Because of the considerable generic homonomy and synonomy in this tribe, the name has changed several times, although Platymantispini is easily characterized by the large first tarsal segment, the elongate terminal process of this tarsal segment, and the insertion of the second tarsal segment before the apex of the first. Males have a coiled penisfilum, while female bear a long ovipositor. As presently constituted, the Platymantispini contains only three American genera, ranging from Argentina north to the United States.

\section{KEY TO GENERA OF PLATYMANTISPINI}

1a. Subbasal spine of fore femur present (Fig. 11, 12) $\ldots \ldots \ldots \ldots \ldots \ldots \ldots .2$

1b. Subbasal spine of fore femur absent (Fig. 10) .................. Trichoscelia

2a. Forewing with five radial veins originating from second radial cell; second radial cell of forewing straight; first and second radial cells of forewing frequently bearing setae on the membrane (Fig. 14). Anchieta

$2 b$. Forewing with two radial veins originating from second radial cell; second radial cell curving around wing apex; first and second radial cells of forewing devoid of setae on the membrane (Fig. 13) ........ Plega

\section{Genus Plega Navás}

Plega Navás, 1928, Revta chil. Hist. nat., 31 (1927): 326.

Type Species: Symphrasis signata Hagen, by original disignation.

This genus was synonomized with Symphrasis by Tjeder (1959), but Parker \& Stange (1965) found Symphrasis to be a synonym of Trichoscelia (confirming the synonomy originally proposed by Gerstaecker, 1888). However, Parker and Stange found several consistent differences between the type species of Plega and Trichoscelia, thus reestablishing the former generic name. The morphological features of Plega include, on the fore femur a "distal median row of sharp tubercles that splits into two rows near the basal one-half. Lateral of the tubercles is a row of setae restricted to the distal half of the femur". Additionally, Plega has a subbasal spine on the fore femur and the second tarsomere of the fore tarsus is longer than in Trichoscelia. Penny (1977) recorded six species of Plega from Brazil north to Mexico. Three additional species were described by Rehn (1939a) from the United States.

\section{Genus Trichoscelia Westwood}

Trichoscelia Westwood, 1852, Trans. R. ent. Soc. Lond., (2) 1: 269

Symphrasis Hagen, 1877, Stett. ent. Ztg., 38: 208.

Type Species: of Trichoscelia is Mantispa fenella Westwood, designated by Enderlein (1910) and of Symphrasis is Rhaphia varia Walker, designated by Enderlein (1910).

The synonomy and homonomy in this genus has led to various tribal and subfamily names, but the current synonomy is as follows: Trichoscelia and Symphrasis were synonomized with Anisoptera Schneider by Gerstaecker (1888). The synonomy of Trichoscelia with Anisoptera Schneider was confirmed by Banks (1913) and of Symphrasis with Trichoscelia by Parker \& Stange (1965). However, Anisoptera Schneider is an Anchieta, with a subbasal spine on the fore femur and other distinctive morphological features. Thus, only Symphrasis is presently a synonym of Trichoscelia.

Trichoscelia was separated from Plega by Parker \& Stange (1965) on the structures of the fore femur- "a submedian double row of setae mesad of which is a double row of minute tubercles, so that there are four parallel rows of setae and tubercles extending along most of the length of the closing face". Trichoscelia also lacks a subbasal spine on the fore femur and the first and second tarsomeres of the foreleg are relatively equal in size.

Penny (1977) recorded 14 species from South and Central America, although several of these species must be transferred to the genus Anchieta. The known range of Trichoscelia is from Argentina north to Mexico. 

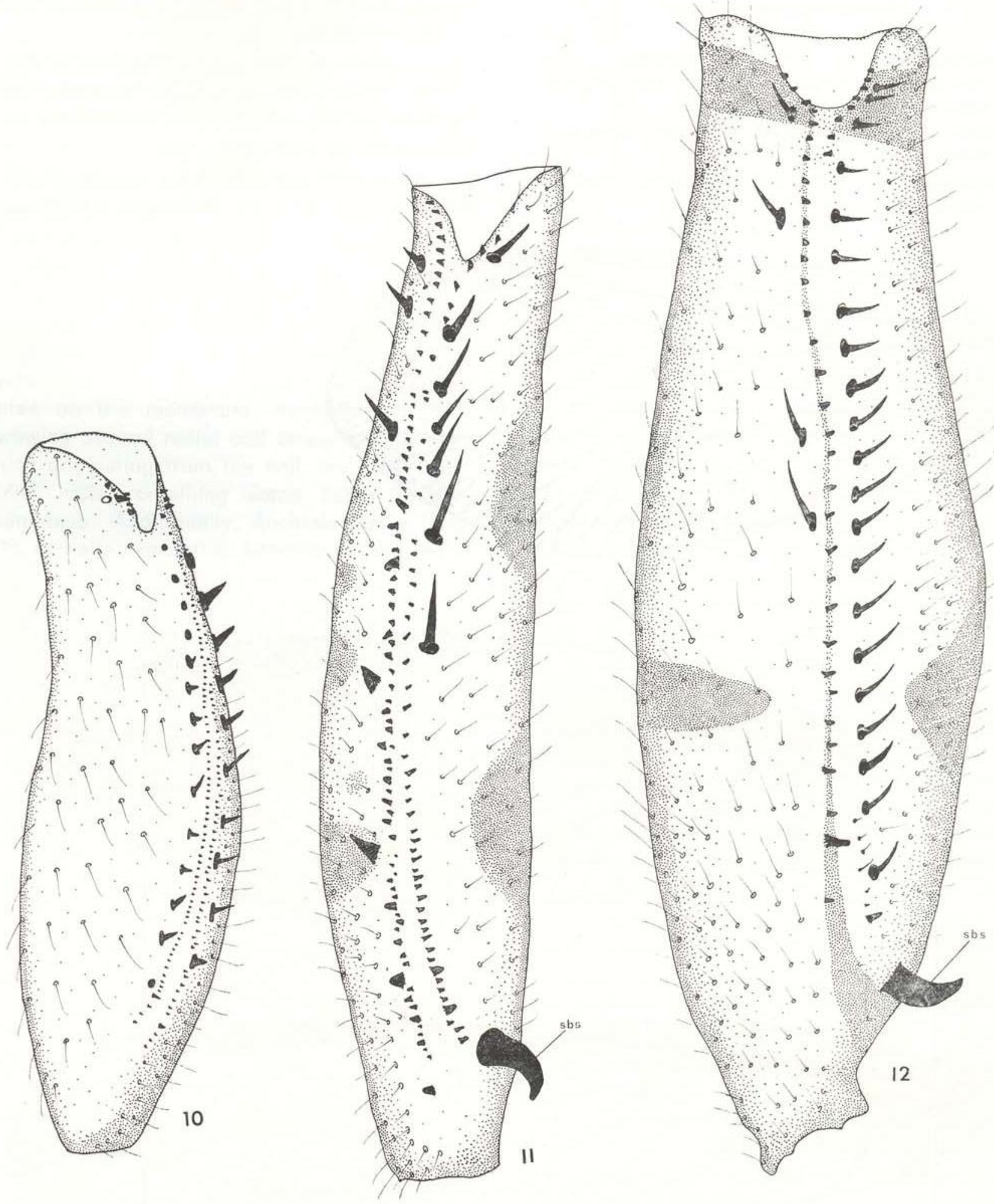

$0.2 \mathrm{~mm}$

Figures 10-12 - Fore femur of 10) Trichoscelia varia (Walker) (left), 11) Plega hagenella (Westwood) (right), and 12) Anchieta nobilis Navás right.

Review of... 


\section{Genus Anchieta Navás}

Anisoptera Schneider, 1843, Mon. Raphidiae, p. 32 (preoccupied by Anisoptera Berthold, 1827, and Anisoptera Herrich-Schaeffer, 1840).

Anchieta Navás, 1909, Mem. R. Acad. cienc. artes Bar celona, (3): $7: 483$.

Platymantispa Rehn, 1939b, Ent. News. 50: 82. (new synonomy).
Anisopterana Strand, 1942, Folia zool. hydrobiol., 11: 389 (new synonomy).

Type Species: of Anisoptera Schneider is Anisoptera notha Erichson (1839), designated by Enderlein (1910); of Anchieta is Anchieta nobilis Navás, by monotypy.

The generic name Anchieta was synonomized with Anisoptera by Enderlein (1910) and

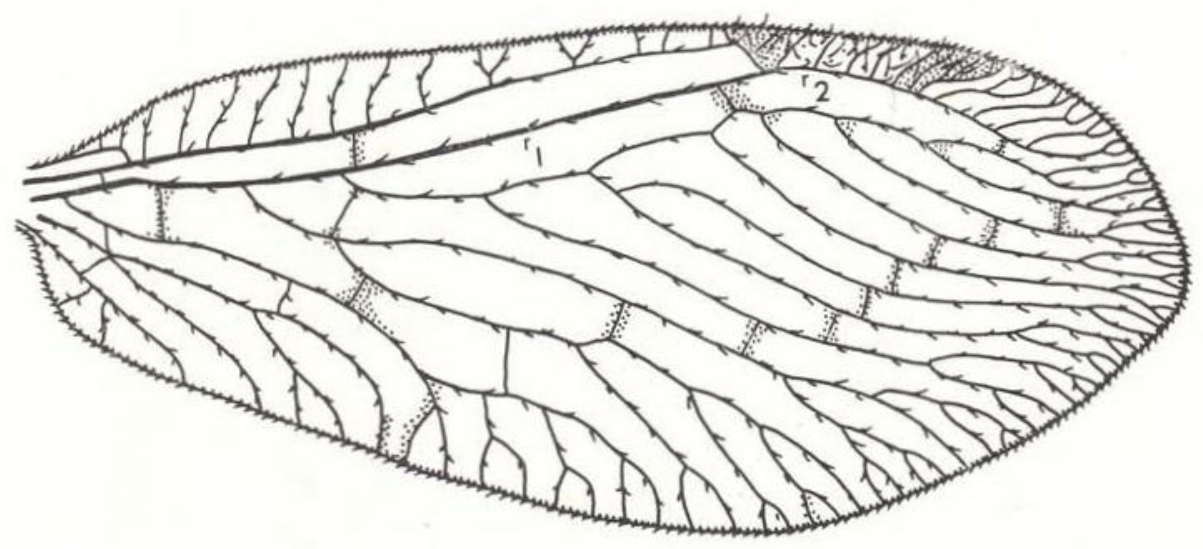

13
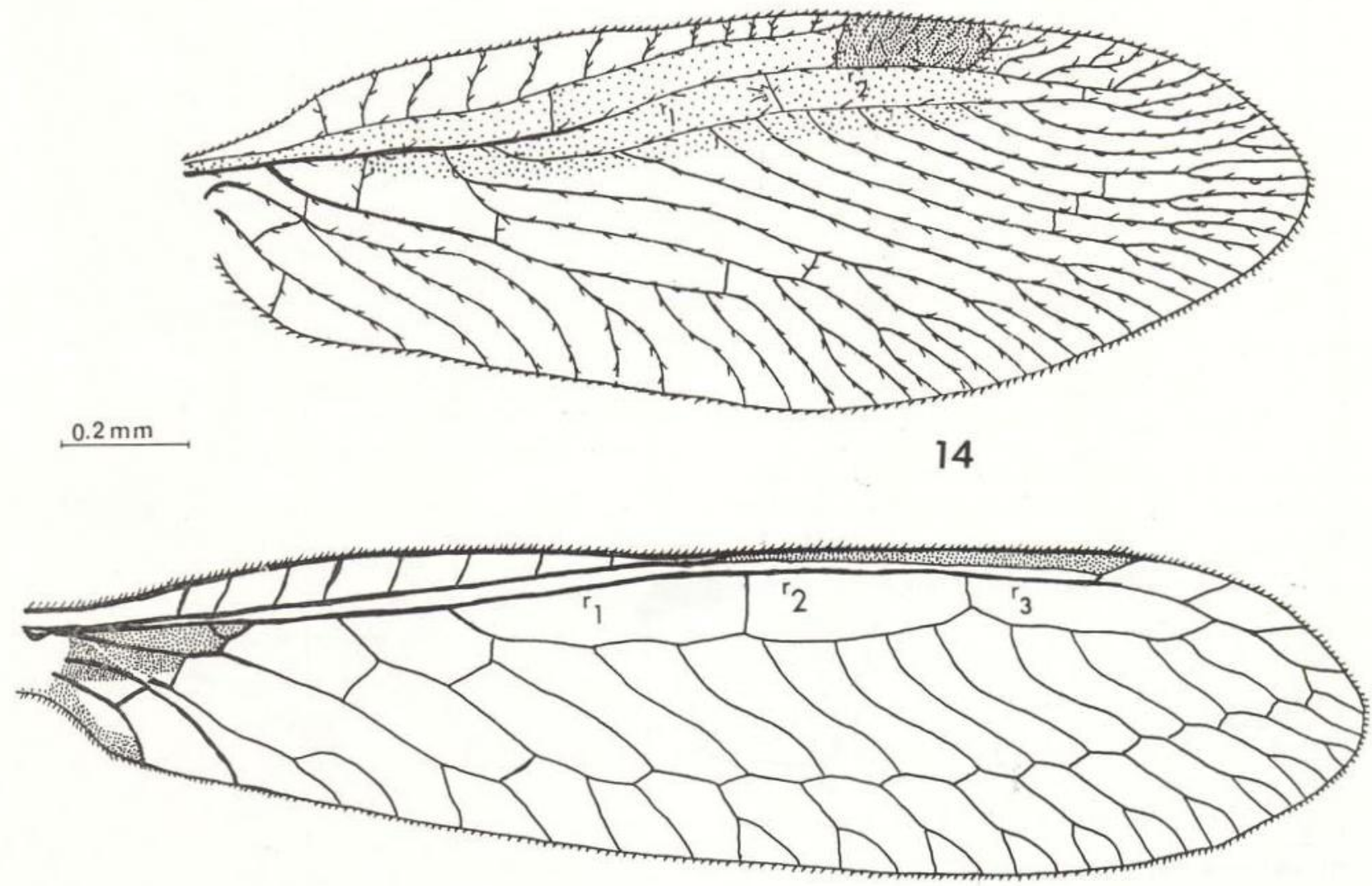

15

Figures 13-15 - Right forewing of 13) Plega hagenella (Westwood), 14) Anchieta nobilis Navás, and 15) Entanoneura chopardi Navás. 
this synonomy was confirmed by Banks (1913). It is here reconfirmed. The names Platymantispa Rehn (1939b) and Anisopterana Strand (1942) are unnecessary additions to the literature when it was independently realized that Anisoptera Schneider was a junior homonym.

This genus possesses the subbasal fore femoral spine of Plega, but the longitudinal row of denticles is reduced to a single row in Anchieta. The majority of differences are found in the radial cells of the forewing. Both Trichoscelia and Plega have the second radial cell curved around the wing apex, with two or three veins originating from this cell, and without setae on the membrane. Anchieta has the forewing second radial cell straight, with five veins originating from the cell, and with both radial cells containing some setae on the membrane. Additionally, Anchieta has a long tuft of hairs emanating laterally to the male genitalia in the single male in the INPA Systematic Entomology Collections. This genus is known from southern Brazil northward to the Amazon Basin and French Guiana. In addition to $A$. notha and $A$. nobilis, $A$. fumosella (Westwood, 1867), A. parthenie!la
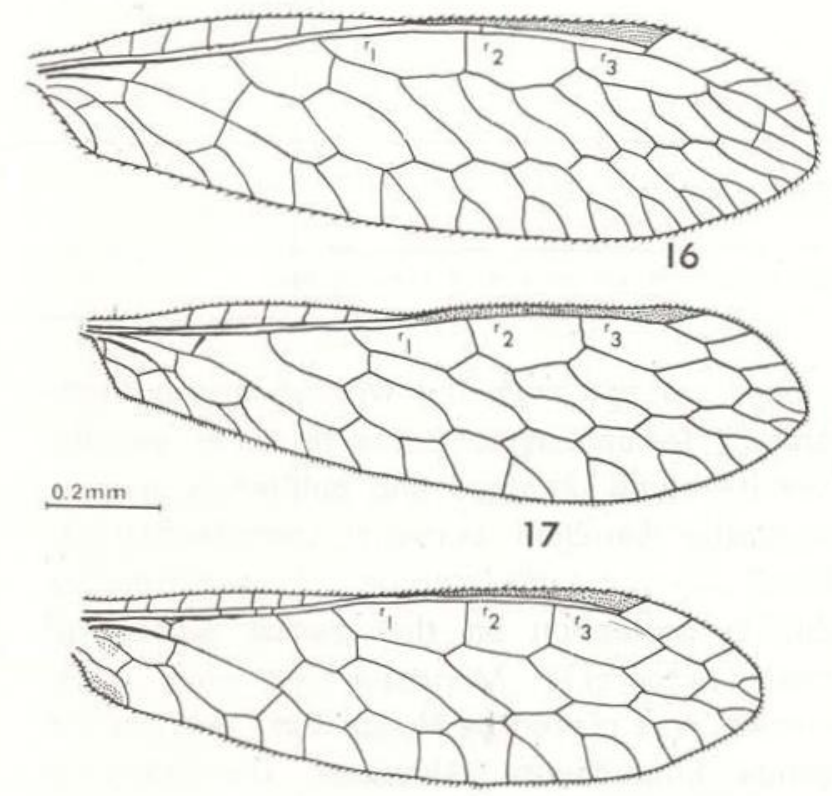

18

Figures 16-18 - Right forewing of 16) Mantispa gracilis Erichson, 17) Mantispa fiavomaculata Latreille, and 18) Mantispa uniformis (Navás).
(Westwood, 1867), A. eurydella (Westwood, 1867) and $A$. bella (Westwood, 1867) are all members of this genus.

\section{Subfamily Mantispinae Leach}

Mantispidae Leach, 1815, Edinb. Encyclop., 9: 139.

Mantispini Navás, 1909, Mem. R. Acad. cienc. artes Barcelona, 7 (10): 184 .

Mantispinae Enderlein, 1910, Stett. ent. Ztg., 71: 341.

Type Genus: Mantispa Illiger (1798).

The Mantispinae are frequently larger than Platymantispinae, have only one tarsal claw, and usually thicker, longer antennae.

This subfamily contains the vast majority of American mantispids. Enderlein (1910) included four genera and a subgenus (Mantispilla) within this subfamily in his revision. Navás subsequently described two new genera, Necyla and Nobrega, and Williner \& Kormilev (1959) synonomized the subgenus and added a new genus. Thus, there has been unti! now seven American genera in the Mantispinae, for which no tribal separation has ever been made.

The characters traditionally used for generic separation in this subfamily are generally weaker than those of the Platymantispinae, making proper identification of this subfamily more difficult. The genera Entanoneura, Necyla and Mantispilla appear to be size variants within the Mantispa complex, and indeed there is a direct relationship between wing length, length of the third radial cell, and number of radial veins (Graphs 1 and 2). Color patterns indicate that the Entanoneura probably are sister species (as herein defined), and the size reduction in Necyla and Mantispilla could also be an evolutionary development of sister groups, although it is not difficult to find specimens of "Mantispa" having the loss of one radial vein of "Mantispilla". Because this character state is so instable, the generic synonomy of Mantispilla and Mantispa is upheld here.

The single described species of Necyla from the New World, Necyla uniformis Navás, has male genitalia quite unlike African and Asian species of this genus, but quite similar to several species of "Mantispa". As was pointed out in graph 1 , the number of radial 


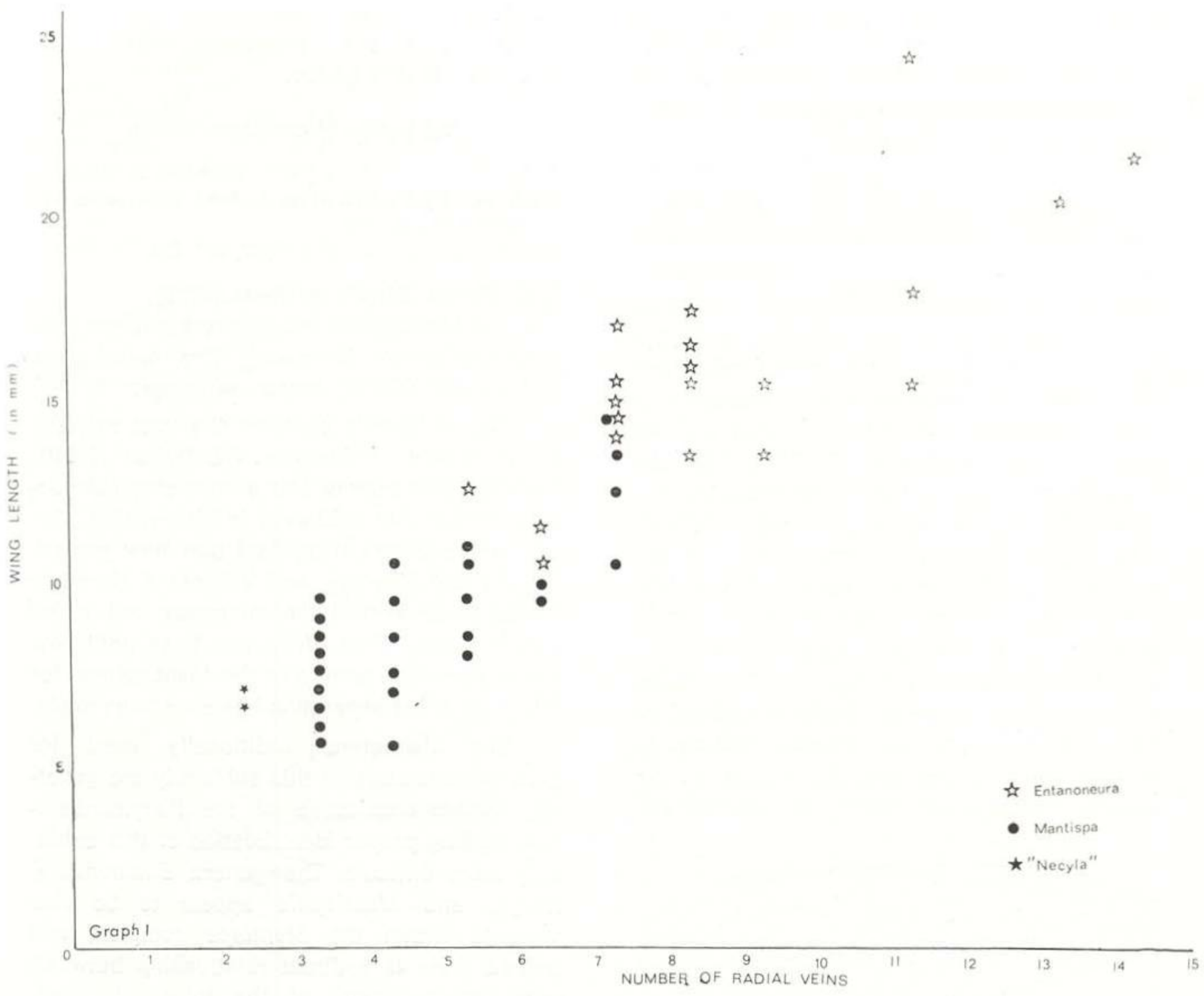

Graph $1-$ Wing length versus number of radial cells in three genera of Mantispinae.

veins seems to be a function of size, so that the genus Necyla, as originally delimited, would contain the smallest members of any evolutionary sequence within the Mantispinae. Thus, the true Necyla, with elongate male ectoprocts, does not occur in the New World.

The genera Paramantispa, Climaciella and Entanoneura, as constituted in this study, are felt to be natural groupings showing uniting apomorphic character states. However, their exclusion from the genus "Mantispa" would leave this genus in a paraphyletic state, unless other natural groupings were also separated as distinct genera. I have chosen to do this in the present keys, but without giving these groups formal names, due to some parallel results being obtained and published upon in Australia (Lambkin, personal communication). Thus, the "gracilis" group has a distinctive double projection on the medial surface of male ectoprocts. Mantispa phthisica Gerstaecker was placed by Handschin (1960) in the genus Entanoneura. However, the elongate, pointed male ectoprocts and dark-tipped wings indicate a closer relationship to some African species of Pseudoclimaciella than to any other American group, and thus is placed in a group by itself. All of the preceding species, and 
Mantispa costalis Erichson, have well developed hypomeres, and all the preceding except $M$. costalis have a heavily sclerotized membrane ( $\mathrm{mp}$ of Tjeder, 1963) between the gonarcus and penisfilum of the male genitalia. M. costalis must form a group by itself due to presence of these characters, and lack of the distinctive characters mentioned for the "gracilis" and "phthisica" groups. Additionally, there is a group of small species which lack the sclerotized $\mathrm{mp}$, and the hypomeres, but which have a well-developed medial process of the gonarcus. These species also generally have the male ninth sternite apically constricted. The species $M$. januaria Navás and M. brunneonigra (Handschin), placed by Hands. chin (1960) in Entanoneura do not show ciose relationships with this genus, and probably form a group of their own, but until male specimens can be examined, their placement is uncertain. Thus, American Mantispinae can be placed in the following groups: Entanoneura, Climaciella, Paramantispa, "gracilis" group, "phthisica" group, "costalis" group, "flavomaculata" group, and perhaps the "januaria" groups.

Nobrega Navás is only a specimen of Climaciella semihyalina lacking much of costal coloration. Thus, this name is herein synonomized.

The Mantispinae range from Argentina north to the United States. No members of this subfamily are known from Chile.

\section{KEY TO AMERICAN GENERA AND SPECIES GROUPS OF MANTISPINAE}

1a. Cubitus of hindwing nearly straight and never coming close to first anal vein (Fig. 20) ................ Climaciella

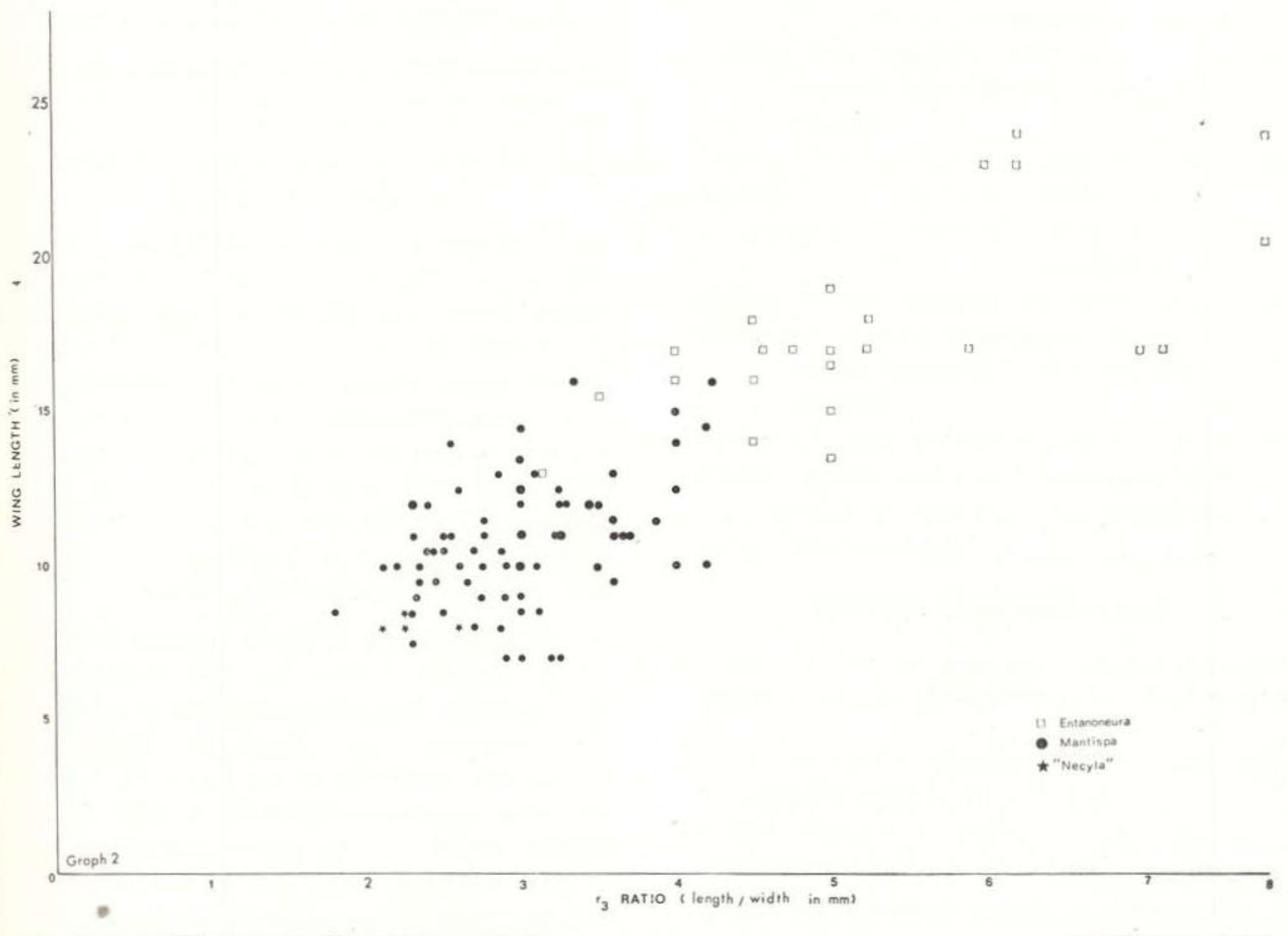

Graph $2-$ Wing length versus $r_{3}$ ratio in three genera of Mantispinae. 
1b. Cubitus of hindwing bending sharply towards first anal vein, then bending sharply away again (Fig. 19) ....... 2

2a. Cubitus of hindwing only briefly touching first anal vein, then angling sharply away again; occipital margin of head often wide (Fig. 22) .............. Paramantispa

$2 b$. Cubitus of hindwing joined to first anal vein for a short distance, then angling sharply away again; occipital margin of head always absent, with eyes reaching hind margin (Fig. 21) ............. 3

3a. Crescent or semicircular marks on pro. zonal region of pronotum .... Entanoneura

$3 b$. Prozonal region of pronotum with longitudinal stripes or small transverse marks, but without semicircular yellow markings ......................... 4

4a. Male ectoprocts bearing two elongate medial projections ...... "gracilis" group

4b. Male ectoprocts bearing at most one medial projection ............... 5

5a. Male ectoprocts elongate and pointed; hypomeres very thin and elongate..... .................. "phthisica" group

5b. Male ectoprocts extending only slightiy beyond ninth sternite, and apically rounded; male hypomeres, if present, not thin and elongate ............... 6

6a. Male ectoprocts bearing medial pointed projection; hypomeres present, but small; medial process of gonarcus absent ....... ................... "costalis" group

6b. Male ectoprocts bearing low, flat medial field of spines; hypomeres absent; media! process of gonarcus well developed ...... ............... "flavomaculata" group

\section{Genus Climaciella Enderlein}

Climaciella Enderlein, 1910, Stett. ent. Ztg., 71: 360. Nobrega Navás, 1914b, Broteria, 12: 233, new synonomy.

Type Species: of Climaciella is Mantispa brunnea Say, by original designation; of Nobrega is Nobrega tinctus Navás, by original designation.

Climaciella is similar to larger species of Entanoneura in having a very elongate third radial cell. However, the hindwing of Clima-

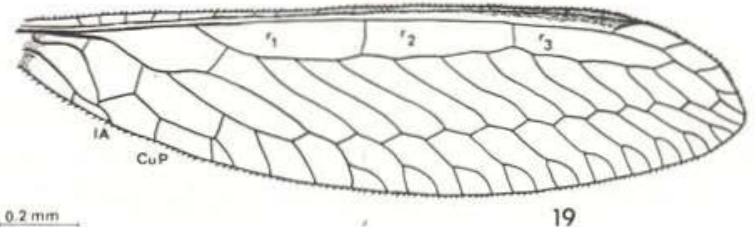

$.02 \mathrm{~mm}$

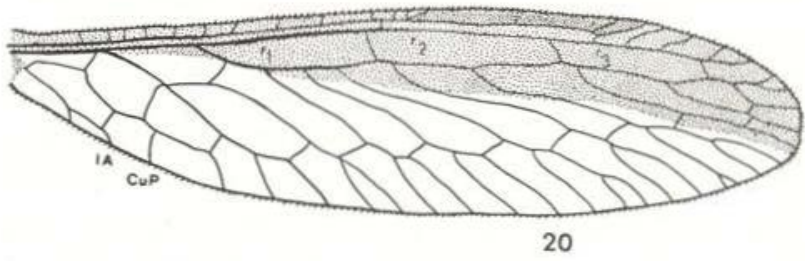

Figures 19-20 - Right hindwing of 19) Entanoneura chopardi Navás, and 20) Climaciella duckei Navás.

ciella always has a straight cubitus, and the anterior border of the wings is darkened. Climaciella is a small genus, with only five species described from Argentina north to the United States.

\section{Genus Paramantispa Williner and Kormilev}

Paramantispa Williner \& Kormilev, 1959, Revta Soc. ent Argent., 21: 10.

Type Species: Mantispa decorata Erichson, by original designation.

This genus is closely related to some of the larger "Mantispas" and Entanoneura in having hypomeres absent, no development of the medial lobe of the gonarcus, but with a well-developed projection on the medial surface of the male ectoprocts. Some of these species are also among the most colorful of American mantispids, with large areas of the wing fully darkened. Four species are known from Argentina, Paraguay, Bolivia and southern Brazil, with one doubtful record from Surinam.

This genus was originally erected by Williner \& Kormilev (1959) for two dark-winged species which had a large occipital area behind the compound eyes. Handschin (1960) expanded the definition of the genus to include two other species much closer to other "Mantispas" based on the brief contact of the cubitus and first anal vein of the hindwing. This has made the genus harder to characterize, although these four species probably do form a natural lineage. 

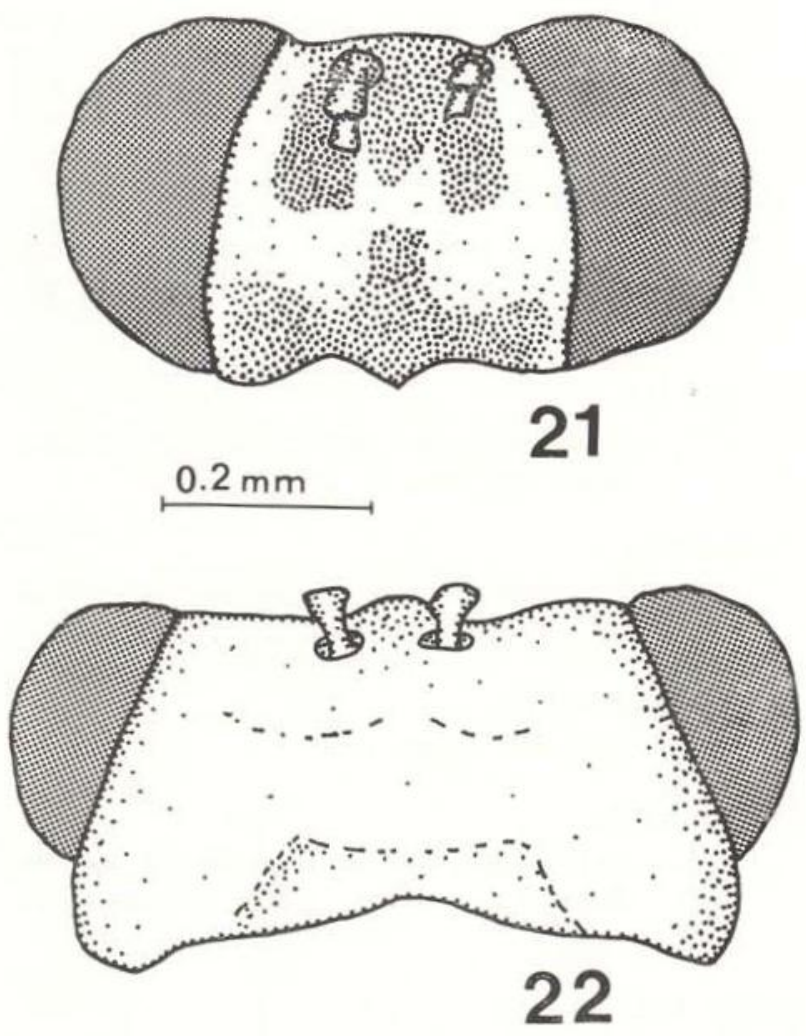

Figures 21-22 - Dorsal view of vertex of 21) Mantispa gracilis Erichson, and 22) Paramantispa decorata (Erichson).

\section{Genus Entanoneura Enderlein}

Entanoneura Enderlein, 1910, Steit. ent. Ztg., 71: 358.

Type Species: Mantispa limbata Gerstaecker, by original description.

This genus has had a variable history due to the weak nature of separating characters. Banks (1913) synonomized Entanoneura with Mantispa, while Williner \& Kormilev (1959) accorded it subgeneric status, and Handschin (1960) described many of the South American species, giving it generic status once again. Penny (1977) listed eight species ranging from Argentina north to Costa Rica.

As defined in this study, M. costalis, $M$. phthisica, and probably $M$. januaria and $M$. brunneonigra are not closely related to other species of Entanoneura, based on the male genitalia, especially the hypomeres and $\mathrm{mp}$. Thus, the genus Entanoneura has a much more restricted number of included species, although the geographical distribution is not changed.

"phthisica" species group

Among all American Mantispinae, this group stands farther apart than the rest, hecause of the distinctive form of the male genitalia. At present, only one species is included in this group. The male hypomeres and sclerotized area $(\mathrm{mp})$ between the mediuncus and gonarcus indicate a primitive position for this species. However, among the American species, none has such elongate hypomeres, nor such elongate, pointed ectoprocts. Some African species appear to have this general configuration of the ectoprocts, but without more detailed study of the genitalia, no closer associations can be determined.

\section{"gracilis" species group}

Like the "phthisica" group, this species group has well-developed hypomeres and a sclerotized $\mathrm{mp}$. However, unlike the "phthisi$c a$ " group, the "gracilis" group has very distinctive projections on the medial surface of the ectoprocts, in some species becoming quite elaborate. Included in this group are $M$. gracilis, $M$. moulti, $M$. lineaticollis and at least one species from North America. The geographical distribution of this group is from Argentina to the United States.

\section{"flavomaculata" spэcies group}

This group is characterized as having very stout male ectoprocts with a low, flat fie'd of medial spines; no hypomeres; no sclerotized area between the gonarcus and mediuncus; reduced size; and often a constricted apex to the ninth sternite. However, the characteristic feature is the development of a medial projection on the apex of the gonarcus which often shows externally above the mediuncus. Many of the species are pale yellow to green in color, although dark species also occur. Thus, the pale green, small species occurring over most of South America, which have been 
identified as flavomaculata, viridula, and the North American species called viridis are included in this group, as are several species from Australia. The geographical distribution thus includes Australia, and in the New World from Argentina north to Wisconsin.

"costalis" species group

This group is intermediate between the first two groups and the "flavomaculata" group, having hypomeres present, bu: no $\mathrm{mp}$ in the male genitalia. Only one species is presently included in this group, $M$. costalis, which also has a number of dense spines on the apex of the ninth sternite. This species is only known from southern Brazil.

Many species of Mantispinae from Cen tral America and some of the North and South American species are still known only from females, or from markings of the wing and body. As these become better known, the present concepts can be better refined, or modified. Then, more considerations on zoogeography can be attempted with the African and Asian species, which also are very porly known, especially with respect to male genitalia.

\section{SUMÁRIO}

A classificação superior de Mantispidae no Novo Mundo é revisado. Chaves são fornecidas para subfamilias, tribos e gêneros para o Novo Mundo. O gênero Fusa é sinonomizado com Gerstaeckerella, Nobrega com Climaciella, Bellarminus com Nolima; e Anchieta é ressurgido. O gênero Mantispa é dividido em quatro grupos de espécies, e o gênero Entanoneura é redefinido.

\section{REFERENCES}

BANKS, $N$.

1913 - Synopses and descriptions of exotic Neuroptera. Trans. Am. ent. Soc., 39: 201-242.

BERTHOLD,

1827 - In Latreille, P.A., Nat. Fam. Thierr., p. 409

BLANCHARD, E.

1851 - In Gay, C., Historia fisica de Chile, zool Orden V. Névroptères. 6: 85-142. Paris.
ENDERLEIN, G.

1910 - Klassification der Mantispiden nach dem Material des Stettiner Zoologischen Museums. Stett. ent. Ztg., 71: 341-379.

GERSTAECKER, A.

1888 - Weitere Beiträge zur Artenkenntniss der Neuroptera Megaloptera. Mitt. naturw. Ver. Neu-Vorpomm., 19: 89-130.

HAGEN, H.A.

1877 - Symphrasis, eine neue Mantispiden-Gattung. Stett. ent. Ztg., 38: 208-211.

HANDSCHIN, E.

1960 - Zur revision süd-amerikanischer Mantispiden. Rev. Suisse Zool., 67: 523-558.

HERRICH-SCHAEFFER

1840 - Nomencl. Entom., 2: 57.

ILLIGER, J.C.W.

1798 - In Kugelmann, Verzeichniss der Käfer Preussens - - - etc. (Halle, Gebauer), 8: 1-510.

LEACH, W.E.

1815 - "Entomology" (Brewster). Edinb. Encyclo., 9: $57-172$

McKEOWN, K.C. \& MINCHAM, V.H.

1948 - The biology of an Australian mantispid (Mantispa vittata Guerin). Aust. Zool., 11: 207. 224.

NAVÁS, L.

1909 - Mantéspidos nuevos. Mems R. Acad. Cienc. Artes Barcelona, 7: 1-15.

1910 - Neurópteros chilenos. Rvta chil. Hist. nat., 14: 235-241.

$1914 a$ - Neuropteros nuevos ó pouco conocidos. Segunda Serie. Mems R. Acad. Cienc. Barce lona, 11 (8): 1-17.

$1914 b-$ Neurópteros sudamericanos. Primeira Serie. Broteria, 12: 45-57, 215-235.

1925 - Insectos neotrópicos. Rvta chil. Hist. nat., 29: $305-313$.

1928 - Insectos neotrópicos (3." Serie). Rvta chil. Hist. nat., 31 (1927): 316-328.

PARKER, F.D. \& STANGE, L.A.

1965 - Systematic notes on Platymantispini. Can. ent., 97: 604-612.

PENNY, N.D.

1977 - Lista de Megaloptera, Neuroptera e Raphi dioptera do México, América Central, ilhas Caraíbas e América do Sul. Acta Amazonica (suplemento). 7 (4): 1-61. 
REHN, J.W.H.

1939a- Studies in North American Mantispidae. Trans. Am. ent. Soc., 65: 237-263.

1939b- Anisoptera Schneider a Homonym (Neuroptera: Mantispidae). Ent. News, 50: 82.

\section{SCHNEIDER, W.G.}

1843 - Mon. Raphidiae, p. 32.

STANGE, L.A.

1968 - Catálogo de Neuroptera de Argentina y Uruguay. Acta zool. lilloana, 22: 5-86.

STRAND, E.

1942 - Miscellanea nomenclatorica zoologica et paleaontologica. Folia zool. hydrobiol., 11: 386-402.
TJEDER, B.

1959 - Neuroptera-Planipennia. The lacewings of southern Africa. 2. Family Berothidae. South African Animal Life, 6: 256-314.

1963 - A new Necyla from Uganda (Neur. Mantispidae). Opusc. Ent., 28: 121-126.

WESTWOOD, J.O.

1852 - On the genus Mantispe. Trans. R. ent. Soc. Lond., 1: 252-270.

WILLINER, G.J. \& KORMILEV, N.A.

1959 - Notas sobre Mantispidae neotropicales, I. (Neuroptera). Rvta Soc. ent. argent., 12: $1-18$.

(Aceito para publicação em 09/09/81) 